\title{
Assessment of road transport infrastructure in Osogbo, Osun State, Nigeria
}

\author{
S. B. Adedotun, D. S. Ogundahunsi \& A. S. Oyeniyi \\ Osun State University, Nigeria
}

\begin{abstract}
The growth and progress of a society is determined and measured to a large extent by the socio-economic development of the city. This is largely dependent on the transportation system of the area. Transportation promotes development in any area and when transportation is hindered, development is also retarded. In Nigeria, and Osogbo, Osun State Capital in particular, the only available mode of transportation is road transport. It provides the linkages between spatially separated facilities, enable social contact, and access to employments. Road infrastructure is a critical ingredient of economic development in the study area. The demands for road transport infrastructure in Nigeria over the years have increased tremendously, while the supplies of road transport services have declined grossly. There is a miss-merge between the demand and supply of road infrastructure in the study area. The study therefore, assessed the availability and adequacy of road transport infrastructure in Osogbo. The study was carried out through personal observation and direct measurement of the available road infrastructure in the study area. The study surveyed 101 kilometres of roads, of which about $77 \%$ of the roads are characterized with potholes and about $88 \%$ of the roads are without walkways which does not make it safe for pedestrians and about $92 \%$ of the roads are without road signs. The study is concluded by suggesting the need for government and public participation in the provision and maintenance of road transport infrastructure in the study area to enhance effective and efficient movement of goods, services and people in the study area.
\end{abstract}

Keywords: road transport, infrastructure, maintenance culture, public participation. 


\section{Introduction}

A well functional and integrated transport system amongst other things stimulates national development and enhances the quality of life of people. It allows markets to operate by enabling the seamless movement of goods and people [1]. Road transportation provides vital links between spatially separated facilities and enables social contact and interaction within man and the environment [2]. It promotes economic development by increasing access to labour and physical resources thus facilitating the realization of a city's comparative advantages. It is the only means of achieving economic and political development [3].

Transport infrastructure refers to the framework that supports our transport system. This includes roads, railways, seaports and airports. Transport infrastructure is a critical ingredient in economic development at all levels of income. Thus the demand for transport services in the country over the years have increased tremendously, while the supply of transport services has declined due to lesser infrastructure in place in the system [2]. Furthermore, any human settlement that is faced with the problem of inadequate facilities and lack of functioning transport facilities has tendency of not functioning effectively. And this can be attributed to lack of proper maintenance on both part of the government and the people.

The only functioning means of transportation in the city studied is the road transport system. Ajiboye and Afolayan [4] noted that road transport is the most common and complex networks while Tunde and Adeniyi [5] maintained that road transport covers a wide range, physically convenient, highly flexible and usually the most operationally suitable and readily available means of movement of goods and services over short and long distances. Road transport infrastructure is an essential element in development of an urban centre which includes the road network, drainages, warning signs, culverts, bus stops, etc.

\section{Statement of the problem}

Problems pervading urban transport sector in most developing countries ranges from inadequate and poor quality of infrastructure, mismatch between demand and supply to increased rate of accidents [6]. The problem of traffic congestion in cities of Nigeria has its roots partly in the structural pattern of the roads especially in the traditional area of cities and the unplanned growth and haphazard land-use distribution [7]. Associated with the traffic congestions are problems of parking. Parking demands far outweigh the available supply in most Nigerian cities [8]. This has resulted in road-side parking and illegal parking, which are common features in urban centers in Nigeria and Osogbo in particular. Likewise, the onstreet offloading and loading of goods in urban centers is also caused by the unavailability of proper structures and infrastructure that should support offloading of goods [9].

Joslin [10] has observed that many roads in Nigeria have little or no effective drainage; very few have culverts or side ditches. During the rainy season (April and October) many roads becomes impassable, as a storm water result in flooding 
that erodes the roadways. Apart from this, most roads typically have few or no speed limit signs or warning signs to alert the motorist of curves, hills, intersections or problems with road itself, such as large potholes or eroded road beds [2].

Unfortunately, the financial and technical requirements for effective maintenance, rehabilitation and reconstruction of the road infrastructure have become so staggering that the rate of maintenance could not be matched with deterioration [11]. The inefficiency and lack of urban road transport services and infrastructure is a major impediment to economic growth and urban productivity in cities of developing countries [12]. This problem has crippled other sectors of the economy such as health care, commercial, industrial and educational facilities. It is in view of this, this study made an assessment of road transport infrastructure in Osogbo, Osun State, Nigeria.

This research work is aimed at assessing road transport infrastructure with a view to identify its adequacy and functionalities and how the available infrastructures are being maintained in the study area. The objectives are to identify and examine the available road transport infrastructure in the study area, and assess the maintenance strategies for the available road transport infrastructure.

\section{The study area}

The city is situated between latitude $7^{\circ} 46^{\prime} \mathrm{N}$, longitude $4^{\circ} 34^{\prime} \mathrm{W}$ and latitude $7.767^{\circ} \mathrm{N}$, longitude $4.567^{\circ} \mathrm{E}$. Osogbo is the capital city of Osun State, and Headquarters of both Osogbo and Olorunda Local Governments. It has an estimated population of 306,228 [12]. The city is situated on a raised land which is well over 500 metres above sea level and it is drained by the Osun River and its tributaries such as Gbanmi, and Omu. Osogbo like any other Yoruba city is a traditional city which grows organically over time. It has grown from a small centre along a number of radial exit roads. Today the city is characterized with a lot of intra-city networks such as the ring roads i.e. West bypass, East bypass, Alekuwodo road, Odi-Olowo road Oke-Fia-Dada Estate road, etc. The growth of these roads has tremendously affects the growth and form of Osogbo today. Figure 1 shows the road network pattern of Osogbo.

\section{Research methodology}

Primary and secondary data were used in the study. Primary data were derived through personal observation and direct measurement of existing road infrastructure along randomly selected twenty six (26) road corridors in Osogbo which is about 101 kilometres. The sample size represents $1.4 \%$ of the existing 1,914 roads identified in the city. The sample size is based on the statistical belief that where a small sample is selected randomly from a large population the result will always give a true representation of the area. Similarly, previous researches (13 and 14) utilized 1\% in their studies. Secondary information on the existing numbers of roads, ownership of the roads and their conditions whether paved or 


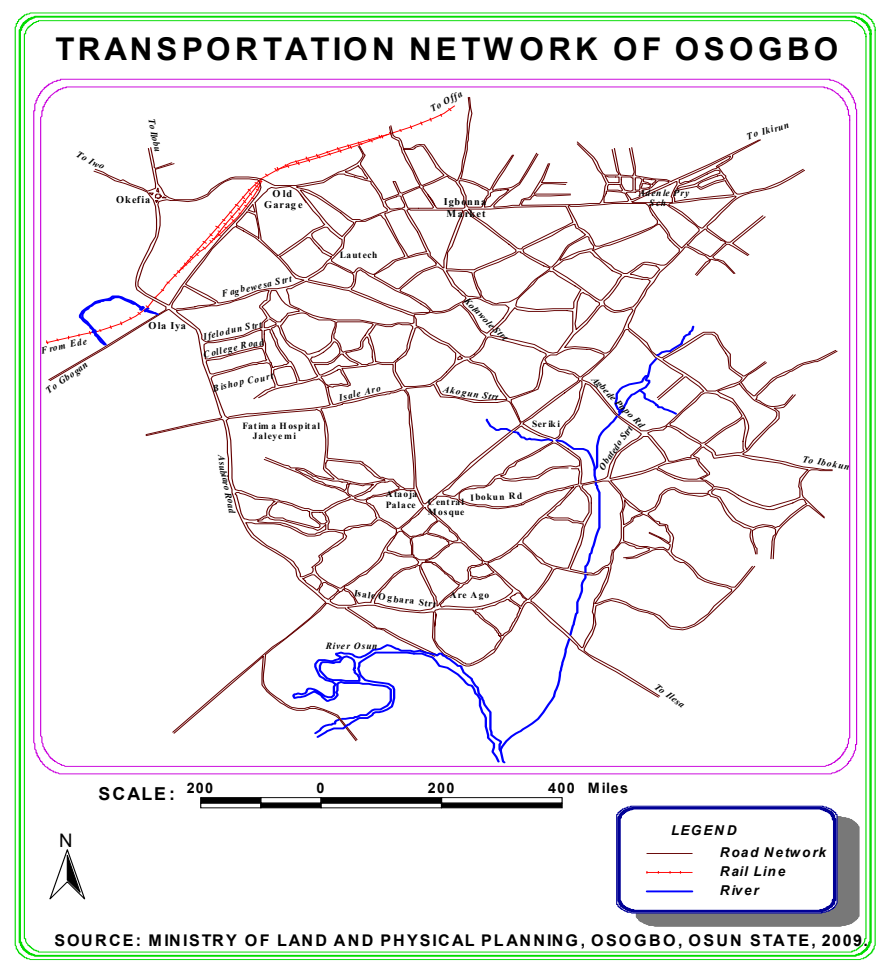

Figure 1: Road network of Osogbo.

unpaved were derived from Osun state ministry of works and transport, Osogbo, Nigeria. Car speedometer was used to determine the length of the sampled roads. Field assistants were employed to do the actual counting and measurement of the depth and width of the pot holes on the selected city roads. The road infrastructure was evaluated on the basis of the following indices: road distances (kms) and lanes, surface conditions (tarred and un-tarred), number, depth and width of pot holes, drainage conditions and assessment of other road infrastructures in the study city.

To evaluate the surface conditions of the roads in Osogbo, the roads are categorized on a scale of 1 to 5. Average of the scale of measurement was used to determine the surface conditions of the roads in the city studied. The categorization scale of the roads is shown in Table 1.

Descriptive statistics such as tabulation, percentages and mean were used to summarize and present data collected.

\section{Presentation and analysis of data}

\subsection{Analysis of roads in Osogbo}

Table 2 shows type of roads and conditions of roads whether paved or unpaved in Osogbo as indicated by the Osun state ministry of works and transport, Osogbo. 
Table 1: $\quad$ Categorization of roads.

\begin{tabular}{|l|c|}
\hline Categories of roads & Rank \\
\hline Not tarred and in disrepair & 1 \\
\hline Not tarred but motorable & 2 \\
\hline Tarred with bitumen but in disrepair & 3 \\
\hline Tarred with bitumen but with potholes & 4 \\
\hline Tarred with bitumen and maintained smooth surface & 5 \\
\hline
\end{tabular}

Source: authors' field work, 2015.

The analysis shows that that there are about 1,914 roads within Osogbo metropolis, out of which $98.32 \%$ are classified as minor roads. The minor roads are owned and manage by the Local governments and the communities. Only $1.68 \%$ of the roads are classified as major roads under the auspices of the State and Federal governments. The analysis reveals that only $4 \%$ of the minor roads in the city are paved, while $96 \%$ are unpaved. However, $90.6 \%$ of the major roads are paved, while $9.4 \%$ are unpaved. Table 2 further reveals that only $5.4 \%$ of roads in Osogbo are paved, $94.6 \%$ are unpaved.

Table 2: $\quad$ Analysis of roads in Osogbo.

\begin{tabular}{|c|c|c|c|c|c|c|}
\hline \multirow{2}{*}{ Road types } & \multicolumn{4}{|c|}{ Road conditions } & \multirow{2}{*}{ Total } & \multirow{2}{*}{ Percentage } \\
\hline & Paved & $\%$ & Unpaved & $\%$ & & \\
\hline Minor & 74 & 4 & 1808 & 96 & 1882 & 98.32 \\
\hline Major & 29 & 90.6 & 3 & 9.4 & 32 & 1.68 \\
\hline Total & 103 & 5.4 & 1811 & 94.6 & 1,914 & 100 \\
\hline
\end{tabular}

Source: Osun State Ministry of Works and Transport, Osogbo.

However, for further in-depth study of road infrastructures in Osogbo, 26 road corridors were sampled and the distances of the roads ranges between 1 kilometre and 18 kilometres (Table 3). In all 101 kilometres of roads were studied. The analysis shows that $73 \%$ of the road surveyed made up of two lanes of single carriage way of about 9 metres. The remaining $27 \%$ of the road surveyed made up of four lanes of dual carriage roads of about 12 metres each. Table 3 further reveals that $7.69 \%$ of the roads sampled are Federal Government roads and $30.77 \%$ belong to State Government which are classified as major roads. The remaining $61.54 \%$ are Local Government roads which are also known as minor roads.

\subsection{Surface conditions of selected roads}

The study reveals that most of the roads surveyed are characterized with a lot of potholes of various sizes. In all, 3,795 potholes were counted as shown in Table 4. It shows that for an average of $1 \mathrm{~km}$, there are about 38 potholes of an average of 0.15 metre deep and 1.00 metre wide. As stated earlier in the methodology, surface conditions of the roads are categorized on the scale of 1 to 5 as contained in Table 1. On the average the surface conditions of roads sampled in Osogbo is rated 3.5 , this is an indication that most $(72.3 \%)$ of the roads surveyed in the city are tarred with bitumen but in the state of disrepair and characterized with potholes. These roads require urgent attention to avoid total collapse. 
Table 3: Distance and lanes of the selected roads.

\begin{tabular}{|c|l|c|c|l|}
\hline S/N & \multicolumn{1}{|c|}{ Routes } & $\begin{array}{c}\text { Distance } \\
(\mathrm{km})\end{array}$ & Lanes & Ownership of roads \\
\hline 1 & Kobongbogboe-Old Garage & 9 & 4 & Federal Government \\
\hline 2 & Arubuola junction-Omigade Road & 3 & 2 & Local Government \\
\hline 3 & Isale Aro-Orita Elelede & 4 & 2 & Local Government \\
\hline 4 & Oke-Fia- Olaiya & 3 & 4 & State Government \\
\hline 5 & Onward Junction-Ori-oke Purewater & 3 & 2 & Local Government \\
\hline 6 & Tinumola-West-bypass ring road & 2 & 2 & Local Government \\
\hline 7 & Orita Asipa-Station Road & 2 & 2 & Local Government \\
\hline 8 & Baruwa Junction-GTB area & 2 & 2 & Local Government \\
\hline 9 & Ilesa Garage Junction-Koledowo Estate & 2 & 2 & Local Government \\
\hline 10 & Salako-Oke-Onitea & 1 & 2 & Local Government \\
\hline 11 & Oke-Ayepe Junction-Ijetu & 2 & 2 & Local Government \\
\hline 12 & Obalende Junction-Ayepe Junction & 2 & 2 & Local Government \\
\hline 13 & Elelede-Gbemu Road & 3 & 2 & Local Government \\
\hline 14 & West bypass ring road & 7 & 4 & State Government \\
\hline 15 & Olaiya-Abere & 6 & 4 & Federal Government \\
\hline 16 & Olaiya-Isale Aro & 3 & 4 & State Government \\
\hline 17 & Oja-oba-Power line junction & 4 & 2 & Local Government \\
\hline 18 & Old garage-Oja-oba-Ilesa garage & 5 & 2 & State Government \\
\hline 19 & Oke-fia-Okinni & 5 & 2 & State Government \\
\hline 20 & Oja-oba-OSBC & 4 & 2 & State Government \\
\hline 21 & Lameco Junction-Capital Hotel & 2 & 4 & State Government \\
\hline 22 & Igbona-Oke onitea & 2 & 2 & Local Government \\
\hline 23 & Nipco Junction-Ataoja Estate & 3 & 2 & Local Government \\
\hline 24 & Ilesa Garage Junction-Aratumi & 2 & 2 & Local Government \\
\hline 25 & East-bypass & 18 & 4 & State Government \\
\hline 26 & Aregbe Bus Stop-Capital Hotel & 2 & 2 & Local Government \\
\hline & Total & & \\
\hline So & Ce: authors' field work, July 2015 & & \\
\hline
\end{tabular}

Source: authors' field work, July 2015.

\subsection{Drainage availability and conditions}

Information from Osun state ministry of works and transport, highways unit, Osogbo reveals three categories of drainage standard in Osun state. These are: Trunk A road $1 \mathrm{~m}$ by $1 \mathrm{~m}$; Trunk B road $0.75 \mathrm{~m}$ by $0.75 \mathrm{~m}$; Trunk C road $0.6 \mathrm{~m}$ by $0.6 \mathrm{~m}$. These categorizations form the basis for the assessment of the existing drainages in the city studied. Table 5 shows the availability of drainage and the conditions of the drainages of the roads studied. The survey reveals that eight (8) out of the twenty-six (26) roads surveyed have no drainage at all. Eight of the roads meet up with the trunk A road drainage standard, four are of trunk B drainage standard, while the remaining six of the roads are of trunk $\mathrm{C}$ drainage standard. The study shows that roads that have drainages are relatively good and of acceptable standard with an average depth of 0.91 metre and 0.82 metre wide. However, some of the drainages are already blocked with refuse and some overgrown with weeds. This had always resulted in storm water on the roads which the result is the collapse of roads being experience in some roads in Osogbo today. 
Table 4: $\quad$ Surface conditions of the selected roads.

\begin{tabular}{|c|c|c|c|c|c|}
\hline $\mathbf{S} / \mathbf{N}$ & Routes & $\begin{array}{c}\text { Surface } \\
\text { condition } \\
\text { (rank) }\end{array}$ & $\begin{array}{c}\text { No. of } \\
\text { potholes } / \mathrm{km}\end{array}$ & $\begin{array}{c}\text { Average } \\
\text { depth of } \\
\text { potholes } \\
(\mathrm{mtr})\end{array}$ & $\begin{array}{l}\text { Average } \\
\text { width of } \\
\text { potholes } \\
(\mathrm{mtr})\end{array}$ \\
\hline 1 & Kobongbogboe-Old Garage & 4 & 42 & 0.15 & 1.4 \\
\hline 2 & $\begin{array}{l}\text { Arubuola junction-Omigade } \\
\text { Road }\end{array}$ & 5 & - & - & - \\
\hline 3 & Isale Aro-Orita Elelede & 5 & - & - & - \\
\hline 4 & Oke-Fia-Olaiya & 5 & - & - & - \\
\hline 5 & $\begin{array}{l}\text { Onward Junction-Ori-oke } \\
\text { Purewater }\end{array}$ & 1 & 267 & 0.18 & 1.5 \\
\hline 6 & $\begin{array}{l}\text { Tinumola-West-bypass ring } \\
\text { road }\end{array}$ & 1 & 340 & 0.16 & 0.9 \\
\hline 7 & Orita Asipa-Station Road & 3 & 36 & 0.15 & 0.8 \\
\hline 8 & Baruwa Junction-GTB area & 3 & 25 & 0.14 & 0.6 \\
\hline 9 & $\begin{array}{l}\text { Ilesa Garage Junction- } \\
\text { Koledowo Estate }\end{array}$ & 2 & 20 & 0.16 & 0.8 \\
\hline 10 & Salako-Oke-Onitea & 2 & 61 & 0.15 & 0.9 \\
\hline 11 & Oke-Ayepe Junction-Ijetu & 2 & 37 & 0.14 & 1.4 \\
\hline 12 & $\begin{array}{l}\text { Obalende Junction-Ayepe } \\
\text { Junction }\end{array}$ & 3 & 41 & 0.18 & 1.1 \\
\hline 13 & Elelede-Gbemu Road & 5 & - & - & - \\
\hline 14 & West bypass ring road & 5 & - & - & - \\
\hline 15 & Olaiya-Abere & 5 & 2 & 0.13 & 0.7 \\
\hline 16 & Olaiya-Isale Aro & 3 & 117 & 0.15 & 1.6 \\
\hline 17 & Oja-oba-Power line junction & 3 & 60 & 0.16 & 1.3 \\
\hline 18 & $\begin{array}{l}\text { Old garage-Oja-oba-Ilesa } \\
\text { garage }\end{array}$ & 4 & 15 & 0.12 & 0.5 \\
\hline 19 & Oke-fia-Okinni & 3 & 82 & 0.15 & 1.3 \\
\hline 20 & Oja-oba-OSBC & 4 & 20 & 0.14 & 0.6 \\
\hline 21 & $\begin{array}{l}\text { Lameco junction-Capital } \\
\text { Hotel }\end{array}$ & 5 & - & - & - \\
\hline 22 & Igbona-Oke onitea & 5 & - & - & - \\
\hline 23 & Nipco Junction-Ataoja Estate & 5 & - & - & - \\
\hline 24 & Ilesa Garage Junction-Aratumi & 2 & 23 & 0.15 & 0.4 \\
\hline 25 & East-bypass & 1 & 19 & 0.16 & 1.2 \\
\hline 26 & Aregbe bus stop-Capital Hotel & 5 & - & - & - \\
\hline
\end{tabular}

Source: authors' field work, July 2015.

\subsection{Availability of other road transport infrastructure}

The study further reveals the level of availability of other road infrastructure in Osogbo, Osun State capital (Table 6). The survey shows that only $15.4 \%$ of the surveyed roads have walkway. This is an indication that pedestrian and vehicles will be competing on the roads, which hinder free flow of traffic in the city. The 


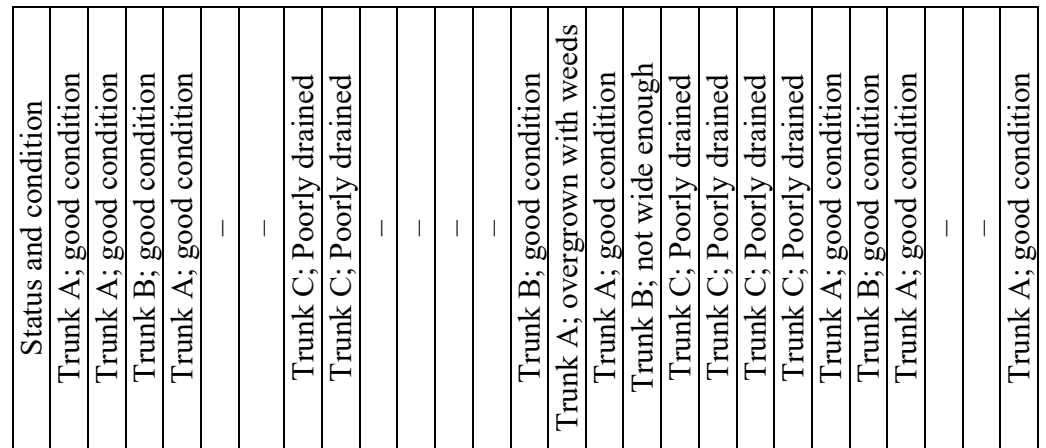

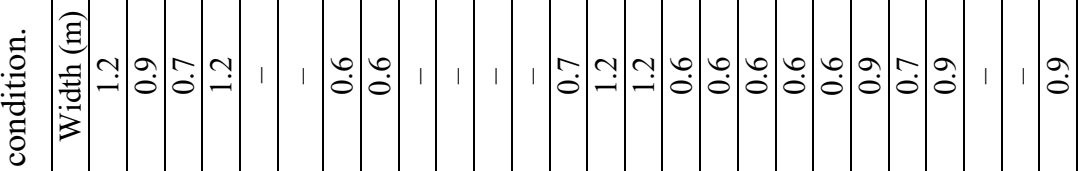

of

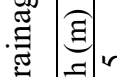

$\Xi$

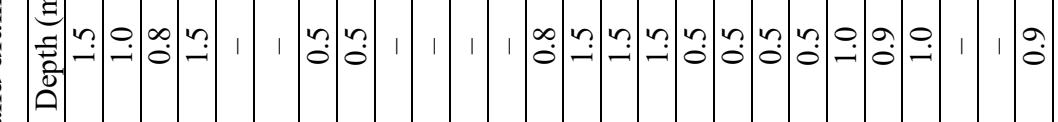

$\stackrel{9}{8}$

晃

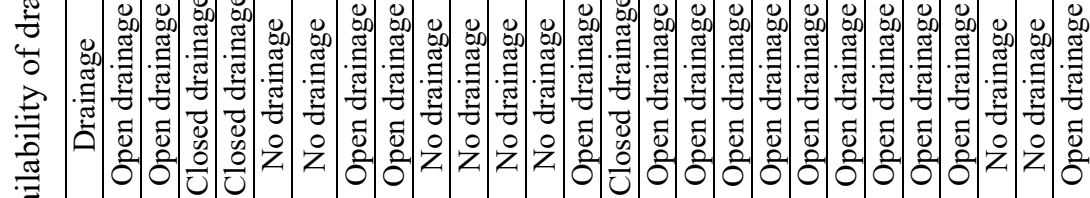

矛

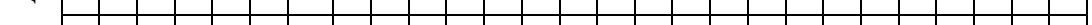

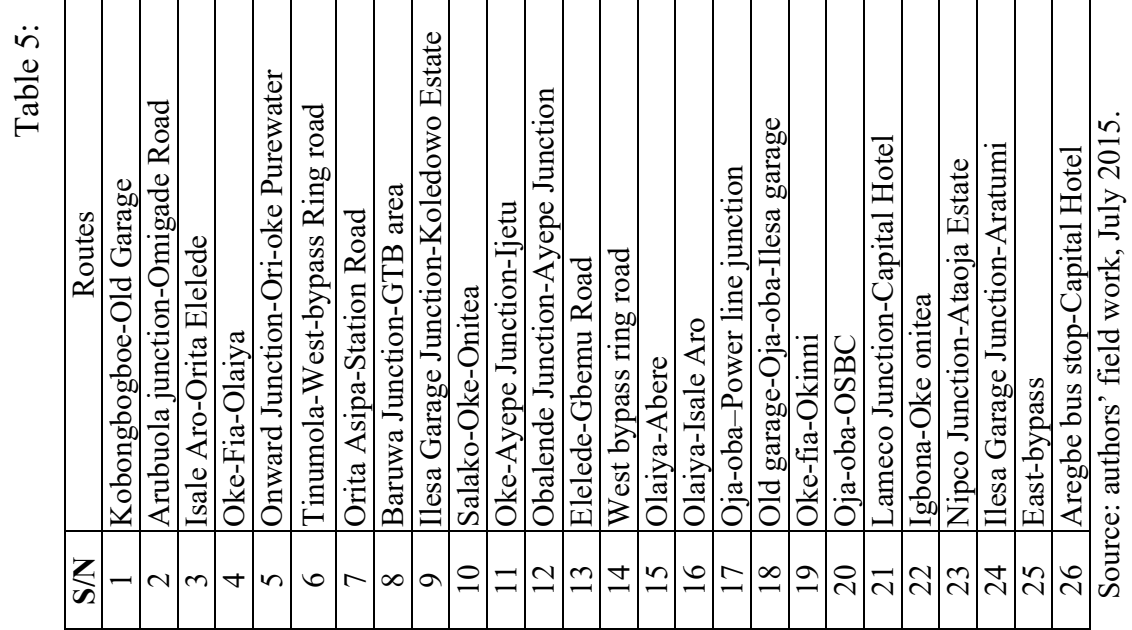




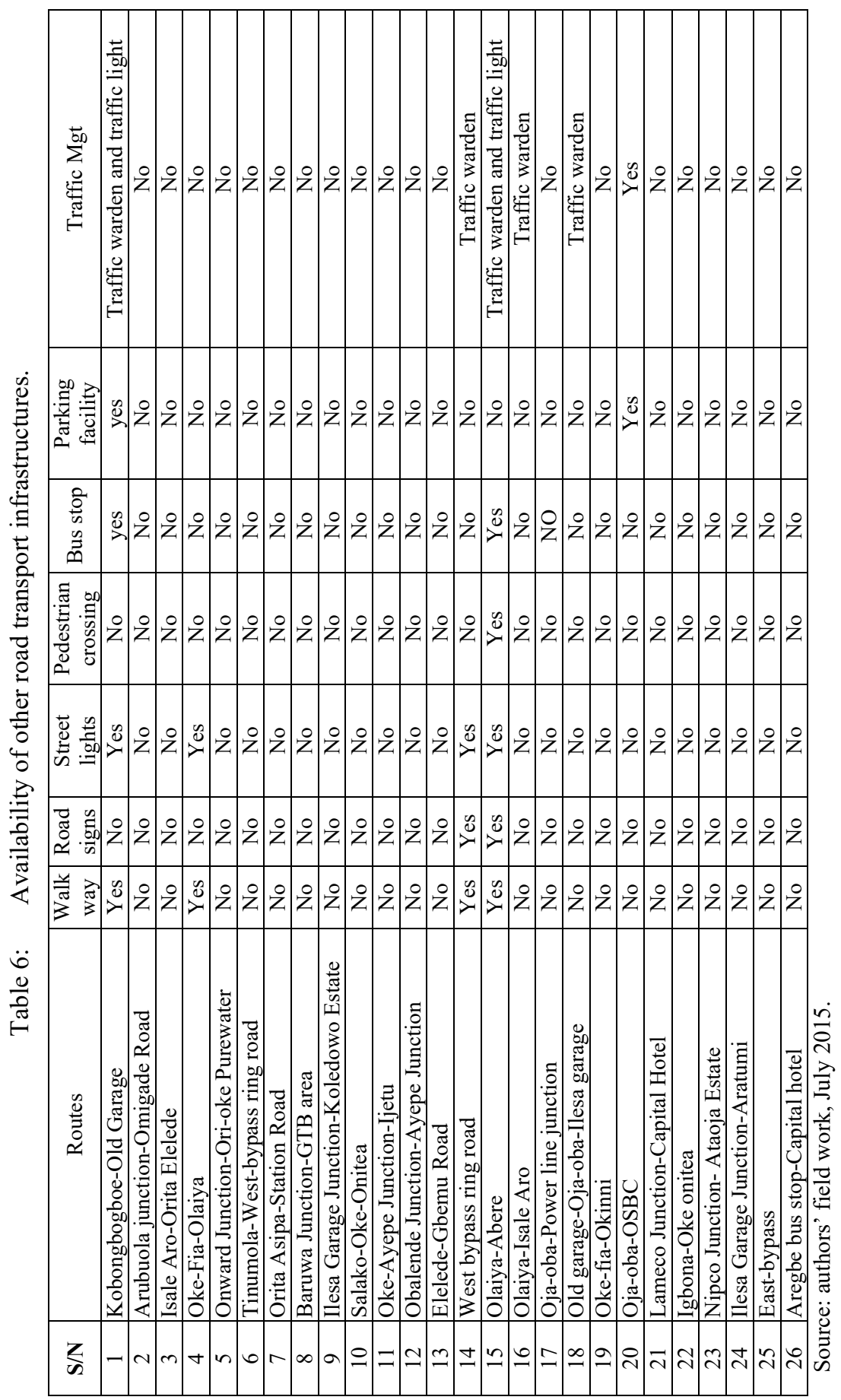


study also reveals that only $8 \%$ of the roads have road signs to alert motorist of the road conditions, while $15 \%$ of the surveyed roads have streetlight. Similarly, $12 \%$ of the roads surveyed have bus stops which accounts for indiscriminate stoppage of both public and commercial vehicles in picking and alighting passengers on the roads' side in Osogbo. This often results in traffic conflict and delay for other motorist and other road users as observed during the field work by the researcher.

The study also reveals that just one of the routes have parking facility which is "Kobongbogboe-Old garage", the parking facility is situated at Old Garage which happens to be the only major parking facility in the whole of the city. It was also revealed that 6 of the identified roads are with traffic warden to control traffic, while just one of the roads has a functioning traffic light to control traffic located at Ola-Iya junction in Osogbo.

\section{Summary of findings}

The study assessed conditions of road transport infrastructure in Osogbo with the aim of identifying availability, adequacy and functionalities of road transport infrastructures in the city. The study surveyed 101 kilometres of roads, of which $73 \%$ of the roads surveyed made up of two lanes, while $27 \%$ made up of four lanes. Most $(77 \%)$ of the roads are characterized with lot of potholes of various sizes. The study shows that for an average of $1 \mathrm{~km}$ there are about 38 potholes. The study further revealed that most $(61.54 \%)$ of the identified roads belongs to the Local Governments, the surface condition of these roads are in a state of disrepair and need urgent attention.

The study reveals that the conditions of the drainages of the selected roads in the study area are extremely bad that need urgent attention to prevent further collapse of the roads. It also clear from the study that basic road transport infrastructure requires for effective intra- city movement such as walkways, road signs, street light, pedestrian crossing, bus stop and parking facilities are conspicuously absent in almost all the roads surveyed. The attributes of these roads can be attributed to the nature of the ownership of the roads which is mostly owned and manage by the third tiers of government. This level of government in Nigeria does not have the financial capability and other resources to handle the level of roads left in their domain.

\section{Conclusion}

It has been asserted in this study that road transport infrastructure facilities are grossly inadequate in the studied city and the few that are available are completely in the state of disrepair calling for urgent attention.

\section{Recommendations}

In view of the present chaotic situation the road transport infrastructure finds itself in Osogbo, the following recommendations are hereby made. First, Government 
at all levels, that is at Federal, State and Local level should accord priority to road development in their budget to enhance smooth and effective movement of goods and services within and without the cities. Secondly, Government should create enabling environment through legislation by the legislative arm of government to support public private partnership in the provision of road infrastructure. This will give legal backing for the operation of public private partnership (PPP) at both the federal and at the state level. It will also give private individuals sense of belongings in the maintenance of road infrastructures. Thirdly, Local government must as a matter of constitution is relief of burdens of road construction and maintenance by the Federal and State Governments. The public also need adequate enlightenment on the need to improve on their maintenance culture. This will enhance durability and sustainability of the few existing road infrastructures.

\section{References}

[1] National Transport Policy for Nigeria (2003): Draft Document, Transport Sector Reform Committee Bureau of Public Enterprises. Abuja: FG of Nigeria, $54 \mathrm{p}$.

[2] Adedotun S.B. and Adedotun D.O. (2014): Road Concession and Pricing: Panacea for Urban Road Sustainable Development in Osun State, Nigeria. International Journal of Comparative Studies in International Relations and Development. Vol.3 No1, July 2014 pp. 47-59.

[3] Adedotun S.B. (1992): 'Intra-city movement' A case study of Ila-Orangun, Osun State. An original Bsc. Degree Essay submitted to the Department of Geography and Regional Planning, Ogun State University, Ago-Iwoye (unpublished).

[4] Ajiboye, A.O. and Afolayan, O. (2009): The Impact of Transportation on Agricultural Production in a Developing Country: A Case of Kolanut Production in Nigeria. International Journal of Agricultural Economics and Rural Development 2 (2) pp. 49-57.

[5] Tunde, A.M. and Adeniyi, E.E. (2012): Impact of Road Transport on Agricultural Development: A Nigerian Example. Ethiopian Journal of Environmental Studies and Management (EJESM) Vol. 5 No. 3 pp. 232238.

[6] Adedotun, S.B. (2015): A study of Urban Transportation System in Osogbo, Osun State, Nigeria. European Journal of Sustainable Development, Vol. 4, No. 3 pp. 93-101.

[7] Aderamo, A.J. (2002): Transport and the Nigerian Urban Environment. Paper delivered at 45th Annual Conference of the Nigerian Geographical Association held at university of Ilorin, 30th June-3rd July 2002.

[8] Kombs (1988): Consultancy Report: Traffic Management Schemes in Metropolitan Lagos. Submitted to the Federal Urban Mass Transit Programme (FUMTP).

[9] Aderamo, A.J. (2012): Urban transportation problems and challenges in Nigeria: A planner's view. www.primejournals.org/pre 
[10] Chris Joslin, (2011): “Traffic and Transportation in Nigeria". www.uni.edu/gai/sites/default/files/less

[11] Abdulkareem, Y.A. and Adeoti, K.A. (2004): Road Maintenance and National Development. National Engineering Conference, Federal Polytechnic Offa, Kwara State, Nigeria.

[12] Oyeniyi, A.S. (2015): "Assessment of road transport infrastructure in Osogbo, Osun State" B.sc. Thesis submitted to the Department of Urban and Regional Planning, Osun State University, Osogbo, unpublished.

[13] Aluko, E.O. (1996): Location and Neigbourhood effects on urban housing values. Case study of Metropolitan Lagos. Unpublished Ph.D Thesis, Dept. of Geography University of Ibadan, Ibadan.

[14] Arimah, B.C. and Adinnu, I.F. (1995): Market segmentation and the impact of landfills on residential property values: Empirical evidence from an African city. Netherlands J. Housing and the Built Environ, 29(2):257-270. 